\title{
DISPUTE RESOLUTION FOR CUSTOMARY LANDS: SOME LESSONS FROM FIJI
}

\author{
Keresi R. Fonmanu \\ Manager - Reserve and Special Project \\ Native Lands \& Fisheries Commission \\ P.O.Box 116 Suva \\ Fiji Islands \\ Email: kfonmanu@nltb.com.fj \\ Lisa Ting \\ Fellow \\ Department of Geomatics \\ The University of Melbourne \\ Victoria 3010, Australia \\ Email: ting@sunrise.sli.unimelb.edu.au \\ Ian P. Williamson \\ Professor of Surveying and Land Information \\ Department of Geomatics \\ The University of Melbourne \\ Victoria 3010, Australia \\ Email: ianpw@unimelb.edu.au
}

\begin{abstract}
Customary land tenure involves a complex and detailed array of tenure rights which are often difficult to reconcile with western systems of land tenure. Land disputes arising from customary land tenure are costly, time consuming and often hinder the operation of governments, land administrators, developers, investors, proprietors and land users. These disputes may be the result of the customary system or the result of the tensions of a dual tenure system. This paper discusses the experience of Fiji in addressing disputes involving customary land and proposes a framework for resolving disputes in customary land.
\end{abstract}




\section{INTRODUCTION}

The introduction of western land tenure systems by colonial administrations and the pressures of achieving economic, social and political aims placed pressures on customary land tenure systems in many countries. The system of land tenure introduced by colonial administrations emphasised individual ownership and use of land primarily for economic purposes, thereby giving land commodity value. On the other hand customary land tenure systems are a way in which communities define wealth (within the community and as social status) and are also significant in defining cultural identity.

While land disputes are common throughout history, the influences of the western system add another level of complexity to customary tenure systems and the resolution of disputes arising from the two systems. Land disputes may arise from the attempt to incorporate customary tenure systems within a western system because the changes are not understood and/or accepted by the people. As a result of increasing efforts by many governments worldwide to accommodate social and environmental considerations in tenure systems, disputes involving customary land require specific administrative procedures by government agencies to prevent violent solutions to these often hostile disputes (Crocombe, 1978, MacAndrews, 1986).

In the case of Fiji, the land tenure system reflects the traditional and social structure of the indigenous Fijians (taukeis) in conjunction with the legislative framework formulated by the former colonial government (Lasaqa, 1984). The present system represents "a long process of evolution, simplification, and institutionalisation" (Overton, 1994). Fiji, like other Pacific nations with a colonial inheritance, has a dual system of land tenure. Eighty four percent of Fiji's total land area are held by the indigenous Fijians with these lands comprising customary lands. The balance is freehold land and state or government owned lands, much of which has developed into the best urban, commercial, industrial and agricultural lands (Rakai, 1993). The dual tenure system has been highlighted as one of the contributing factors to the economic disparity that exists in Fiji today and as a contributing factor in land disputes.

For a detailed review of land tenures in Fiji see Lloyd (1982), Rakai (1993) and Rakai et al (1995) although there is a vast number of articles and books addressing this topic.

The objective of this paper is to consider how customary land administrators can minimise and resolve conflicts and disputes where customary land systems seek to incorporate western land administration concepts. In addressing this objective the paper analyses the dimension of disputes involving customary lands in Fiji, considers some dispute resolution strategies from neighbouring countries and proposes a solution to resolving customary land conflicts.

\section{DiSPUTES INVOLVING CUSTOMARY LANDS IN FIJI}

Land disputes involving customary lands in Fiji have three main dimensions, being land administration, land tenure and ownership and land boundaries. Land administration being the way in which government formally administers the land. Land tenure refers to the formal and informal rights in land. Land boundaries are the ways in which the people demarcate where the boundaries of their rights and responsibilities begin and end. Disputes involving these dimensions occur within the customary land tenure system and between the western and customary systems. 


\section{Land Administration}

The administration of customary affairs in Fiji is the responsibility of the Ministry of Fijian Affairs. The three main organisations that deal with customary lands are the Native Lands and Fisheries Commission (NL and FC or commonly known as Native Lands Commission, NLC), the Native Land Trust Board (NLTB) and the Fijian Affairs Board (FAB). The Fijian Land Information System (FLIS), operating under the Department of Lands was established to improve the management of lands in Fiji and actively coordinates the needs of landowners through these three administrative bodies mentioned above (Rakai and Williamson, 1995). However while FLIS contributes to upgrading and facilitating access to native lands data, it does not actively coordinate the needs of the landowners.

Although government departments and statutory bodies manage customary lands, the landowners themselves have significant powers over the management of their land. Their role as customary landowners cannot be ignored and their decisions concerning developments proposed for their land can be crucial to the economic development of the country. Since most of the land in Fiji is held under customary tenure, it is important that all customary issues are addressed through appropriate land administration procedures.

\section{Land Tenure}

As summarised by Rakai et al (1995) the customary tenure system is based on Fijian customs and traditions, and applies to all Native Lands (until they become Native Leases which are under the 'western' system). Though these lands make up almost $84 \%$ of Fiji's total land area, only about $31 \%$ of this is actually accessible cultivable land and it is usually leased to non-Fijians. This leaves the indigenous Fijians or taukei with lands that are in difficult terrain, not easily accessible, and of lower quality and marketability.

With the exception of the portion of lands that are leased out, Native Lands include those lands that are farmed/used by the taukei for their subsistence and, increasingly, commercial needs, as well as Native Reserves - lands that in principle, have been set aside to be used exclusively by indigenous Fijians.

Lands under this traditional land tenure system work on the principle of communal ownership of a land parcel that has already been topographically surveyed, charted on Native Land Commission Maps, and registered in the Register of Native Lands (RNL). Under this system land and communal land owners are registered, with no individual titles being issued. Ownership of land is vested in the mataqali or tribal group as registered in the RNL. Individual membership of the land owning mataqali or tribal group is recorded in the Vola ni Kawa Bula (VKB).

The Native Lands Commission, established under the 1905 Native Land Ordinance, is responsible for maintaining the VKB and resolving land disputes. In addition, since 1940 , it is also responsible for demarcating and recommending to the NLTB, areas to be reserved for the future use of the taukei.

Native lands cannot be sold; and any dealings or works to be done on or with respect to the land requires the approval of the majority of the members of the mataqali that are over 21 years of age. Legally the final approval/decision rests with the NLTB. Although Native Lands cannot be sold, they can be officially leased out, with the consent of the mataqali landowners, through the NLTB. Once leased out they naturally come under the 'western' system of land tenure for the duration of the lease, as previously mentioned. 
One of the advantages of the traditional tenure system for the taukei is that it has prevented outright land sales and land speculation, and thus has ensured that the taukei have not become a landless people in their own country. Another advantage is that it has helped the taukei to maintain their land-based customs and traditions, which are based fundamentally on the maintenance of family and kinship ties, and ultimately on the basic principles of sharing and caring. Ironically however, it is this very principle that has been one of the major stumbling blocks in the taukei's quest for economic progress.

\section{Land boundaries}

Native lands boundaries were traditionally demarcated with piles of earth, gravel, stones or rocks depending on the material available. Unfortunately these are vulnerable to destruction by natural causes and are not reliable for demarcation purposes.

The Department of Lands undertook surveying of native lands in Fiji 80 years ago using different approaches to that of freehold or leasehold lands. The resulting maps charted mataqali land parcels. They were compiled from topographical surveys that were carried out by a variety of methods, ranging from those using prismatic compass, tape and plane-tables, to those using conventional surveys, and even aerial photography and photogrammetry (Rakai et al, 1995).

Customary lands were not subject to individual ownership, had no established market value, and were not surveyed and mapped precisely. The high cost of cadastral survey is one of the many obstacles which was encountered by the early Native Lands Commission (NLC) when undertaking surveys of native lands (Williamson, 1982).

\section{EXAMPLES OF LAND DISPUTES}

As stated above the three main types of disputes involving customary lands results from land ownership, land boundaries and the administration of customary lands. Detailed below are some examples to illustrate common land disputes primarily involving customary lands in Fiji. The examples used in this section are taken from Keresi Fonmanu's original research into land disputes involving customary lands in Fiji (Fonmanu, 1999).

\section{Disputes arising from land administration}

This sub-section covers disputes that arise from the way in which land policies and management practices are administered for customary lands in Fiji. The following examples detail common disputes involving administration of customary lands.

Case 1: Lack of acceptance of formal institutions - The Ministry of Fijian Affairs includes the Native Land Trust Board, which is the sole custodian of all Fijian lands. The Native Lands Commission determines the ownership of native land while the Fijian Affairs Board administers the daily activities of Fijian rural life. The mandates of these organisations sometimes overlap and as such the advice they give to landowners may conflict. Disputes may therefore arise if different landowners choose to follow conflicting advice provided by the various authorities.

Case 2: Transfer of land - The colonial administration attempted to accommodate the native system within its land policies. Traditional transfers were conducted through conquest, dowry for women and gifts for chiefs. Customary land practices did not require registration to prove ownership. The influence of colonial administration and 
the rigid rules that accompanied the rights to transfer land prevented the traditional transfer system from being completely included within the colonial administrative system. The dual systems created confusion and caused some disputes.

Case 3: Lack of coordination and communication between administrative bodies - The three administrative bodies mentioned in Case 1 manage their own discrete land policies and strategies, with a shared objective of improving rural Fiji. The differing ideas of how rural Fiji may be improved are very political and are an obvious catalyst for further disputes involving the administration of land. The lack of coordination and communication between the three administrative bodies is a contributing factor to many of the disputes that arise.

Case 4: Expiration of Agricultural Landlord and Tenants Act leases - The Agricultural Landlord and Tenants Act (ALTA) was introduced in 1966 in the sugar cane belt to provide security of land tenure and the incentive to increase productivity. ALTA provided security of lease tenure for the duration of thirty years. As most ALTA leases are now expiring, there is an impending triangular issue between the landowners, the tenants and the NLTB. The expiration of land subject to ALTA leases and slow renewal of these leases have introduced uncertainty in many of the ALTA lands and within the sugar cane industry. As sugar cane is imperative for the economy of Fiji, such uncertainty will greatly affect the nation.

Land disputes involving the administration of land are tabled below. The table attempts to categorise dispute cases and the influences, whether it be at a legislative level, directly involving customary landowners or the many administrative arms that operate in Fiji.

\begin{tabular}{|l|l|l|l|}
\hline $\begin{array}{l}\text { Dispute Cases } \\
\text { (Land Administration) }\end{array}$ & Legislation & $\begin{array}{l}\text { Customary } \\
\text { landowners }\end{array}$ & Administration \\
\hline \hline Conflicting interests in administration & & $\checkmark$ & $\checkmark$ \\
\hline Rigid rules in land policies & $\checkmark$ & & $\checkmark$ \\
\hline $\begin{array}{l}\text { Confusion over administrative } \\
\text { responsibilities }\end{array}$ & & $\checkmark$ & $\checkmark$ \\
\hline Security of Lease & $\checkmark$ & $\checkmark$ & $\checkmark$ \\
\hline ALTA & $\checkmark$ & $\checkmark$ & $\checkmark$ \\
\hline Absentee Land owners & $\checkmark$ & $\checkmark$ & \\
\hline
\end{tabular}

Table 1: Summary of land disputes involving the administration of customary land.

The administration of land in Fiji is mainly encompassed within a western ideal of managing land for economic imperatives. As a result the disputes tabled above have all been influenced by western systems in the operation of a dual land tenure system. However the administration of land within a customary system deals primarily with the distribution of mataqali lands and the management of lands in a manner that continues the traditions and customs of the indigenous population which are often in conflict with this western ideal.

Disputes involving land tenure issues 
The following examples are typical of land ownership disputes encountered in Fiji involving the reconciliation of the customary tenure system and western tenure systems.

Case 1: Use of mataqali land - Land disputes may arise out of denial of the use of mataqali land for personal and economic enterprise. Customary land is vested in the mataqali unit and can only be used commercially if approved by the head and the members of the mataqali. Often rivalry amongst the members of the mataqali may influence decisions concerning land development and the management and administration of customary land.

Case 2: Lease revenue - One of the most common disputes is between members of the mataqali regarding revenue collected from leases and the unfair distribution of lease monies. Tenants are charged rents at the rate of up to $6 \%$ per annum on unimproved value. Lease monies are distributed so that $25 \%$ is retained by the NLTB for administration cost, the Turaga ni Vanua (chief of the District) receive 3.75\%, Turaga ni Yavusa (chief of the village) gets 7.5\%, Turaga ni Mataqali (chief of the mataqali) receive $11.25 \%$ and the members of the mataqali receive $52.5 \%$ (Rakai, 1993). The situation is exacerbated with increasing populations of the mataqali and the consequently diminished availability of land, placing a greater pressure on the lands currently utilised and leased.

Case 3: Traditional / Customary leases - A vakavanua lease is a customary lease that is not recognised by "western" Fijian common law. In most cases the arrangement is made with the head of the land owning unit, who accepts the traditional request for land on behalf of his mataqali. The head of the mataqali is not bound by statutory laws or guidelines and as such, may demand money or goods from his tenants. Disputes occur when these agreements are abused such as when the head of the mataqali requests an exorbitant amount of money or goods for the use of land.

\section{Case 4: Village reserves}

In many cases, the land where a village is situated has not yet been reserved as a 'village reserve'. If land is not reserved for the village, then the mataqali holds the ownership powers in the village. This conflicts with the social system, where the head of the yavusa (village) is the only recognised chief in the village. Conflicts may arise between these three authorities: the village site land owners, the headman of the mataqali and the chief of the village.

\section{Case 5: Customary inheritance laws}

Legal adoptions are not recognised in the Vola ni Kawa Bula (Register of Customary Land owners [VKB]). Although a child has been legally adopted and registered in the Register of Births to the adoptive parents, this child will be shown and registered to natural parents in the VKB. The adopted child may inherent chattels but not the lands of the adoptive parents.

Types of disputes involving land tenure issues are in a Table 2. There are dispute cases on customary ownership that may involve both reserve land and communal land. Some of these cases will also affect the landowners' rights and the recognition of those rights in the VKB. 


\begin{tabular}{|l|l|l|l|}
\hline Dispute Cases (Land ownership) & Communal & Reserve & VKB \\
\hline \hline $\begin{array}{l}\text { Disputes arising from conflicts between } \\
\text { Customary and Western systems }\end{array}$ & & & \\
\hline Individualism & $\checkmark$ & $\checkmark$ & \\
\hline Ignorance over economic development & $\checkmark$ & $\checkmark$ & \\
\hline Dual ownership over reserve claims & $\checkmark$ & $\checkmark$ & \\
\hline Reference to practices before the independence & $\checkmark$ & $\checkmark$ & $\checkmark$ \\
\hline Lease money distribution & $\checkmark$ & $\checkmark$ & $\checkmark$ \\
\hline Village reserves & $\checkmark$ & $\checkmark$ & \\
\hline $\begin{array}{l}\text { Disputes arising from conflicts } \text { within Customary } \\
\text { systems }\end{array}$ & & & \\
\hline Vakavanua leases & $\checkmark$ & $\checkmark$ & \\
\hline Extinct mataqali land & $\checkmark$ & $\checkmark$ & $\checkmark$ \\
\hline Rights over forest land & $\checkmark$ & $\checkmark$ & \\
\hline Unmarked Ownership & $\checkmark$ & $\checkmark$ & \\
\hline Land owners Vs Land users & $\checkmark$ & $\checkmark$ & \\
\hline
\end{tabular}

Table 2: Summary of land disputes involving land tenure rights.

The disputes involving land ownership or perceived ownership involving customary land are influenced not only by the customary system but also by the introduced western system.

\section{Disputes over land boundaries}

Common land disputes that arise in Fiji often involve land boundaries, the location of property and the spatial extent of interests in land. Examples of common disputes are described below.

Case 1 : Boundary definition - In Fiji, disputes over land boundaries are common. As already noted, all surveys on customary lands have been performed to a lower degree of precision than in the western system, the demarcation of such boundaries having utilised natural features and resources. Land disputes may arise as a result of boundary marks being destroyed or where land boundaries can no longer be identified, thereby introducing uncertainty.

Case 2: Transition from customary to western, overlapping boundaries - The overlapping of customary and western land tenure boundaries results in disputes between freehold/ state owners and indigenous Fijian landowners. Disputes may arise when groups are not aware of the boundaries and land users have adversely encroached on the neighbouring property.

Case 3: Individualism versus community - Fencing of properties on customary lands is a sign of selfishness in communal living. Fencing displays individual ownership, with the result that within a communal land holding arrangement this act may cause conflicts between close families and mataqali. Traditionally land boundaries are ultimately of the mind, in a cognitive fashion. 
Case 4: Loss of customary knowledge pertaining to boundaries - Boundaries of unsurveyed lands are fading from the memories of community members and sometimes the land owners themselves are unsure. Elders with the knowledge of the boundary locations are dying, while the younger population are migrating away from the rural areas in search of employment. As knowledge systems erode over time, land disputes arise due to uncertainties in the location of boundaries and the spatial extent of traditional interests in land.

Although this paper has given only a few examples of land boundary disputes, Table 3 outlines other disputes that are encountered in Fiji over land boundaries. The presence of disputes involving land boundaries may pertain to surveyed, unsurveyed and reserved boundaries. Disputes not only arise from conflicts between customary and western systems but also from within customary systems such as the lack of demarcation of customary land boundaries.

\begin{tabular}{|l|l|l|l|}
\hline $\begin{array}{l}\text { Dispute Cases } \\
\text { (Land Boundaries) }\end{array}$ & $\begin{array}{l}\text { Surveyed } \\
\text { Boundary }\end{array}$ & $\begin{array}{l}\text { Reserve } \\
\text { Boundary }\end{array}$ & $\begin{array}{l}\text { Unsurveyed } \\
\text { Boundary }\end{array}$ \\
\hline \hline $\begin{array}{l}\text { Disputes arising from conflicts between } \\
\text { Customary and Western systems }\end{array}$ & & & \\
\hline Boundary marks destroyed & $\checkmark$ & $\checkmark$ & \\
\hline Redefinition survey & $\checkmark$ & $\checkmark$ & $\checkmark$ \\
\hline Fencing & $\checkmark$ & $\checkmark$ & $\checkmark$ \\
\hline Description of boundaries & $\checkmark$ & $\checkmark$ & $\checkmark$ \\
\hline Leasehold boundaries & $\checkmark$ & $\checkmark$ & $\checkmark$ \\
\hline General boundary description & $\checkmark$ & $\checkmark$ & $\checkmark$ \\
\hline Unidentified boundaries & $\checkmark$ & $\checkmark$ & $\checkmark$ \\
\hline Unregistered boundaries & & $\checkmark$ & \\
\hline $\begin{array}{l}\text { Disputes arising from conflicts within } \\
\text { customary systems }\end{array}$ & & & \\
\hline Abuse of sacred sites & & $\checkmark$ & \\
\hline Village boundaries & $\checkmark$ & $\checkmark$ & \\
\hline
\end{tabular}

Table 3: Summary of land disputes involving land boundaries.

\section{EXPERIENCES FROM REGIONAL NATIONS}

A brief review of land administration, and customary land disputes and their resolutions in Western Samoa, Vanuatu, Papua New Guinea and Indonesia identify some principles and experiences which may serve as useful guidelines in developing suggestions to resolve customary land disputes in the Fijian context.

Western Samoa: The Samoan Land Titles Court deals with customary queries and disputes only. The President or Deputy and at least two Samoan judges and two Samoan assessors exercise this Court's jurisdiction. The Court applies law relating to customs and usage in their judgements (Schmidt, 1994, O'Meara, 1995).

Vanuatu: It has been recognised in Vanuatu that land disputes should be resolved at the lowest possible level. This means at the village or family clan level, since 
customary disputes and their resolutions are the duty of the customary leaders or family elders (Rodman, 1995).

Papua New Guinea: Because of the diversity of languages and customs in Papua New Guinea (700 language groups), government has recognised that a local government authority should be established in the provinces where customary information may be collected, stored and utilised publicly by the land owners (Cromcombe and Hide, 1987, Lakau, 1994 and Iatau and Williamson, 1997).

Indonesia: Ting (1996) makes the following recommendations, amongst others, for dispute resolutions in Indonesia:

- Informal negotiation methods suited to the local community (there are over 200 language groups in Indonesia);

- Total commitment by government to train officers for serving the community; and,

- Mobile mediation teams that must be trained in mediation techniques and should have diverse skills such as quasi-legal training and also a firm knowledge of adat (customary law).

\section{DISPUTE RESOLUTION OPTIONS FOR FIJI}

From the principles and experiences shown above and the work of researchers such as Condliffe (1991) and Jandt and Pedersen (1996), a framework for resolving disputes involving customary lands can be proposed. The primary lesson is that there is a need for a system and dedicated organisation for dispute resolution. In the case of Fiji, the main criteria that should influence the development of such a system and organisation in Fiji are:

- Many land disputes are proceeding through the courts. The economic cost of such a trend for a small developing nation is onerous.

- Court cases on land disputes are prolonged because of lack of information on customary land and customary land ownership;

- Information on customary land is not easily accessible by the public. Land owners are poorly educated as to the land records, legislation and policies pertaining to ownership and responsibilities in land;

- Land administrators must gain knowledge of customary land principles;

- Legislation should accommodate the dynamic nature and flexibility of customary laws;

- Government should provide a system for the resolution of customary disputes which is financially viable and expeditious;

- The dispute resolution model must be acceptable to the customary land owners; and,

- Customary land disputes should wherever possible be resolved at the local or village level.

\section{Centre for Dispute Resolution}

Based on the above, the establishment of a Centre for Dispute Resolution (CDR) for Fiji is proposed which will encompass not only the administrative requirements of land disputes but will also have training and educational functions. The primary objective 
is to establish a centre that will efficiently and effectively handle customary land disputes. Further to this, the CDR should:

- Utilise appropriate customary information;

- Disseminate land based information;

- Minimise the financial expenses required for resolving land disputes;

- Resolve disputes in the shortest time possible; and,

- Establish an effective training program for land owners, mediators, administrators, tenants, land users and government officials.

It is proposed that the structure for a dispute resolution organisation should incorporate three main administrative sections as follows:

(a) Customary Disputes Section

(b) Dispute Tribunal

(c) Training and Education Section

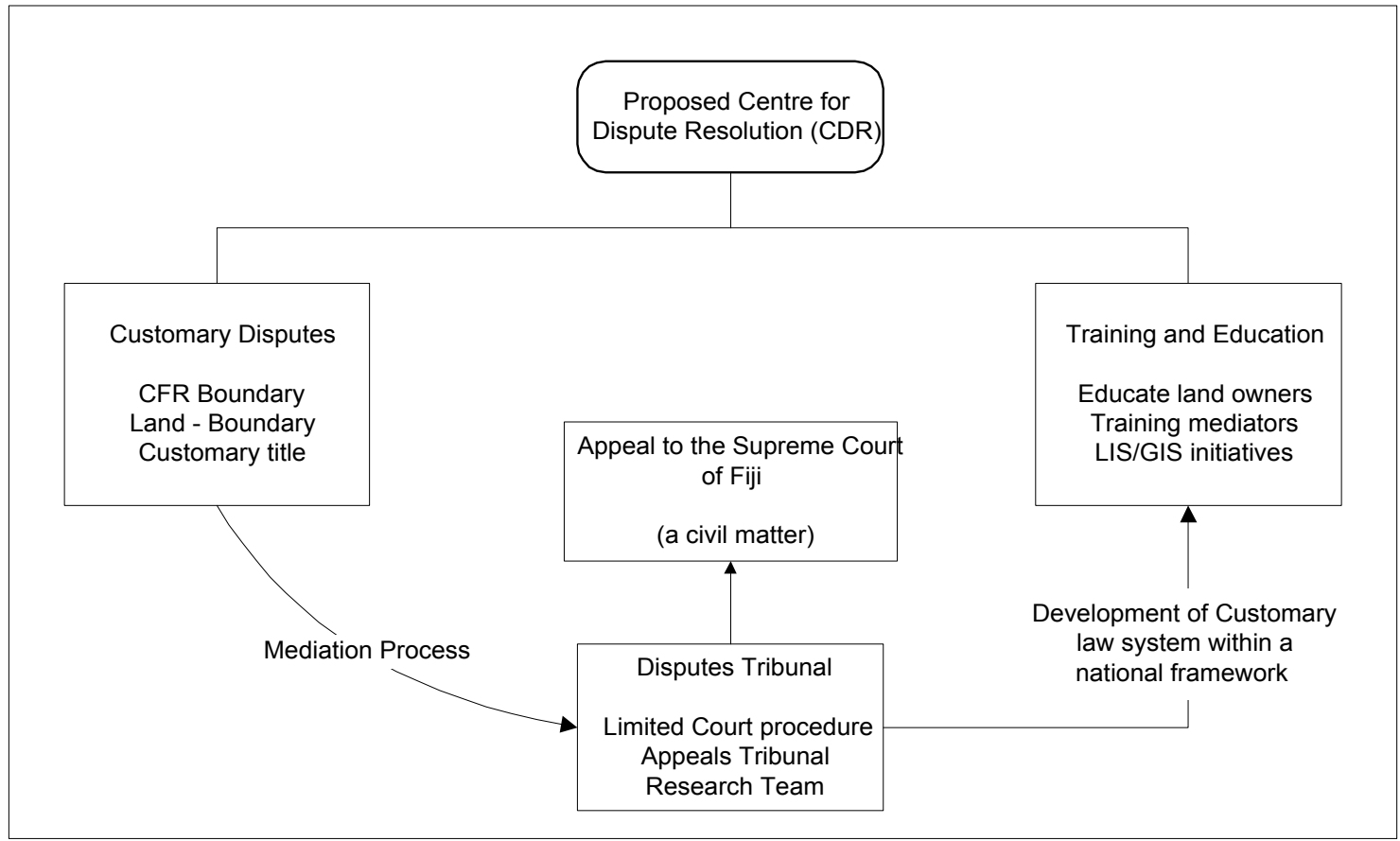

Figure 4: Proposed Centre for Dispute Resolution

\section{Customary Dispute Section}

The Customary Dispute section would apply a process of mediation whereby qualified mediators assist in the process of resolving disputes before they are presented to the tribunal. It is envisaged that mediation will assist in dispute resolution through:

- Encouraging both parties to discuss the dispute in a non threatening and independent manner, with the guidance of mediators; and,

- Discerning the core issues within the dispute, so that if it proceeds to the tribunal most issues and dispute details have been reviewed.

Through the mediation process valuable time and money will be saved, hence the objective of minimising financial expenses and reducing dispute time are partially met.

The disputes presented at this stage of the process should encompass not only customary lands but also include disputes over fishing rights and customary title within the customary law system. 


\section{Disputes Tribunal}

The establishment of a Disputes Tribunal to handle land disputes after a compulsory mediation process ensures that the process is not dominated by a legal process which can promote an adversarial environment. Before a dispute case is presented to the Tribunal it should have undergone mediation within the Customary Dispute section.

The Tribunal should have two roles. The first is to decide the dispute based on customary laws and the second is to provide an appropriate procedure for appeals to the Supreme Court of Fiji as a civil matter if required. This tribunal's members should also include lay people with knowledge of local.

The compilation of records detailing customary tenure in an appropriate manner will be another role undertaken within the Tribunal so as to preserve knowledge of traditional and cultural information.

\section{Training and Education Sector}

The training and education sector will aim to educate and train customary land owners, native tenants, native land lessees, administrators and field workers as to the appropriate procedure for resolving land disputes. The training and education will facilitate the need for land owners to be educated in the legislative knowledge pertaining to their ownership. Through training and education of land owners and land users it is hoped that an increased involvement in land matters will result from these efforts. The training and education section will also be responsible for collecting, storing and updating all land information and other customary information, in collaboration with the Fiji Land Information System. As previously stated, an objective of the proposed Centre is to provide a training and education program detailing the appropriate methods and techniques to be employed for resolving land disputes. It is envisaged that through educating the public on the Fijian land tenure system that disputes will reduce in numbers, further addressing the Centre's objective of reducing the time and money involved with seeking resolution to land related disputes.

\section{INSTITUTIONAL FRAMEWORK}

This paper proposes that any model for land dispute resolution for Fiji should incorporate a Centre for Dispute Resolution whose objective is non-violent solutions for land disputes. Three options for the location of the Centre in the Fijian Government structure are proposed below. It is suggested that all options could be applicable to most Pacific countries, with modification to reflect different geographic and administrative or political environments.

Option 1: Within the Provincial Office Structure - The Provincial Office structure could be extended to manage all customary land information in Fiji, however since customary disputes are unevenly spread across Fiji, one CRD may cover more than one province. With the introduction of the computerised VKB system in the provincial offices, relevant information from other sources could then be installed on this system so that all necessary customary information is easily available for dispute resolution. Option one would then provide easy access to all land information serving both customary and non-customary land owners (Native Lands Act Cap. 133 Section 14).

In Fiji, the Provincial Offices could also introduce a Participator Rural Appraisal system (PRA) based on the system in southern Africa, directing the land owners to 
tackle and manage their problems using formal techniques (group problem solving approaches). This approach "can have a direct impact on the ability of a local community to manage its own problems, including land management issues" (Fourie and van Gysen, 1996).

Option 2: Expanding the Native Lands Commission - The second option proposed involves expanding the NLC (which already administers most customary land disputes), by establishing a section responsible for resolving disputes involving customary lands.

A key component that has been discussed in this paper is the importance of the availability of all information for the resolution of customary disputes. Since the NLC office is located in Suva, the recommendation made by Ting (1996) in regard to mobile mediation teams would appear appropriate and could be incorporated into the new section of the NLC.

Option 3: Under the jurisdiction of the Ministry of Fijian Affairs - This option proposes to establish the CDR within the Ministry for Fijian Affairs. The CRD would then become a new department independent from the existing NLC, NLTB and the FAB. As a result, it will not have any established customary information or records. A review of the present legislation would need to be made to ensure the centre will have access to information that is otherwise classified.

An advantage of setting up the CDR in this manner is that it would be cheaper than expanding the fourteen provincial offices as proposed in Option 1 and would be more accommodating and accessible to non-Fijians than Options 1 and 2. Unfortunately non-Fijians are neither employed in the Provincial Offices nor in the NLC and as such it is proposed that they be included in the new organisation to provide assistance to tenants and proprietors who are leasing indigenous Fijian land. One disadvantage is that it will be difficult for land owners to come to the CDR in Suva or to have access to the information at the Centre unless mobile mediation teams are employed or the Centre is decentralised.

Considering the above options, it is proposed that the location of the CDR is as an administrative unit within the NLC establishment. The justification for this location is as follows:

- All the evidence, records and other tribal and historical books of all customary land inquiries are kept in the NLC;

- The NLC is currently responsible for customary land disputes under the Native Lands Act Cap 133 Section 5;

- The customary land owners know and trust the work of the NLC and see the NLC as providing the best resolution of disputes; and,

- One of the continuing duties of the NLC is to update the Register of Native Land owners (VKB); this is the most important source of information in disputes involving customary lands.

\section{CONCLUSION}

The three main sources of land disputes in Fiji highlighted in this paper include the lack of effective administration to resolve customary land disputes, disagreements

involving customary ownership and the lack of well-defined boundaries for customary lands. Disputes arise on both customary lands and western lands however this paper 
has concentrated on the disputes that involve the customary lands of Fiji. The lack of appropriate institutional infrastructure to address customary land disputes has significantly affected many land reform programs. To address this need the proposed Centre for Dispute Resolution would need to:

- Clarify the procedure for resolving customary land disputes;

- Educate customary land owners on their customary and legislative rights and responsibilities, both within the customary and western land tenure systems;

- Assist in the identification of customary land boundaries;

- Manage and update all customary information; and,

- Facilitate mediation, tribunal and court proceedings which have the flexibility to apply customary laws, where appropriate, in their decisions.

It would be necessary to upgrade the relationship and involvement between the NLC land information system and the FLIS network in the Department of Lands so that all the native lands information in Fiji can be utilised to the maximum. It can be argued that many or most of the disputes arise because appropriate information is not available, is not being managed properly or not being used. While improved information is not the whole solution it is an important ingredient in any solution.

The negative impacts caused by land disputes in Fiji exacerbate social tensions, unduly hinder the operation of an efficient land market, affect initiatives for sustainable development and limit improvement of the land administration infrastructure of the nation. The recognition of the adverse affects of land disputes has highlighted the need for an efficient and effective framework for resolving land disputes for both customary and western land tenures in Fiji. It is recognised that the conflicts that arise within customary land tenure systems as well as between customary and western land tenure systems will always be complex. However the establishment of institutional structures that formally and legally acknowledge these tensions is an important first step for the economic, social and political stability of Fiji.

\section{Acknowledgments}

The authors wish to thank Australian Agency for International Development, the Government of Fiji and the members of the Centre for Spatial Data Infrastructures and Land Administration at the University of Melbourne

(http://www.sli.unimelb.edu.au/research/SDI_research/) in supporting this research.

The authors also wish to gratefully acknowledge the assistance and guidance of Dr. Chukwudozie Ezigbalike, Development Management Officer, Development Information Services Division, United Nations Economic Commission for Africa, in the preparation of this article.

\section{Acronyms}

Agricultural Landlord and Tenants Act (ALTA); Centre for Customary Dispute (CDR); Fijian Affairs Board (FAB); Fisheries Commission (FC); Fiji Land Information System (FLIS); Native Lands Commission (NLC) ; Native Land Trust Board (NLTB); Participatory Rural Appraisal system (PRA); Register of Customary Land owners (VKB). 


\section{References}

1. Condliffe P. (1991) Conflict Management: a practical guide, Collingwood, Victoria, TAFE Publications, RMIT Ltd, 3-8.

2. Crocombe, R. and R. Hide (1987) "New Guinea" in Crocombe R. (ed) Land Tenure in the South Pacific, Suva: University of the South Pacific, 324-367.

3. Crocombe, R. (1978) "Land: Resource or Obstacle" in Crocombe R. and H. Van Trease (prep) Principles and Problems of Land Tenure: Reader Vol 1, Suva: Extension Services, University of the South Pacific, 216-220.

4. Fonmanu, K.R. (1999). Dispute Resolution for Customary Lands in Fiji. Department of Geomatics, The University of Melbourne. Master of Applied Science thesis. http://www.sli.unimelb.edu.au/research/publications/IPW_online thesis.htm

5. Fourie, C. and H. van Gysen (1995) "Constructing Cadastral Reform Theory in South Africa", Geomatica, [49] (3): 315-328.

6. Iatau, M. and I.P. Williamson (1997) "Using the Case Study Methodology to Review Cadastral Reform in Papua New Guinea", The Australian Surveyor, [42] (4): 157-165.

7. Jandt, F. E. and P. Pedersen (1996) "Culturally Contextual Models for Creative Conflict Management in Jandt F. E. \& P. Pedersen (eds.), Constructive Conflict Management Asia - Pacific Cases, California: Sage Publications, 3-8.

8. Lakau, A.A. (1994) "Customary Land Tenure and Economic Development in Papua New Guinea" in Crocombe R \& Meleisea M (ed) Land Issues in the Pacific, New Zealand: Macmillan Brown Centre for Pacific Studies, University of Canterbury, 79-84.

9. Lasaqa, I. (1984), The Fijian People Before and After Independence, Maryborough: Australian National University Press, Dominion Press-Hedges \& Bell.

10. Lloyd, D.T. (1982), Land Policy in Fiji, Occasional Paper No. 14, London: Department of Land Economy, University of Cambridge.

11. MacAndrews, C. (1986) Land Policy in Modern Indonesia, USA: Oelgeschlager, Gunn \& Hainn Publishers, Inc.

12. O'Meara, T. (1995) "From Corporate to Individual Land Tenure in Western Samoa" in Ward, R.G. \& E. Kingdon (ed) Land, Custom and Practice and Practice in the South Pacific, U.K.: Cambridge University Press, 109-156.

13. Overton, J. (1994) "Land Tenure and Cash Cropping in Fiji" in Crocombe R. \& Meleisea M. (eds), Land Issues in the Pacific, New Zealand: Macmillan Brown Centre for Pacific Studies, University of Canterbury,117-132.

14. Rakai, M. (1993) Fiji: Incorporating Customary Land Tenure into a Land Information System. Department of Surveying and Land Information, The University of Melbourne. Master of Surveying Science thesis.

15. Rakai, M. and I.P.Williamson (1995) "Implementing LIS/GIS from a Customary Land Tenure Perspective - The Fiji Experience", The Australian Surveyor, [40] (2): 112-121.

16. Rakai, M., I.C. Ezigbalike, I.P.Williamson (1995) "Traditional Land Tenure Issues for LIS in Fiji”, Survey Review, [33] (258): 247-262.

17. Rodman, M. (1995) "Breathing Spaces: Customary Land Tenure in Vanuatu" in Ward, R. G. \& E. Kingdom (ed.) Land, Custom, and Practice in the South Pacific, U.K.: Cambridge University Press. 
18. Schmidt, G.N. (1994) "The Land and Titles Court and Customary Tenure in Western Samoa" in Crocombe R. \& Meleisea M. (eds). Land Issues in the Pacific, New Zealand: Macmillan Brown Centre for Pacific Studies, University of Canterbury, 169-182.

19. Ting, L.A. (1996) Indonesian Perspective and Approaches to Negotiation and Dispute Resolution. Law School, The University of Melbourne. Master of Laws thesis.

20. Williamson, I. (1982) "The Cadastral Survey Requirements of Developing Countries in the Pacific Region - with particular reference to Fiji", Survey Review [26] (206): 355-366. 


\section{University Library}

\section{- M M I E R R A A gateway to Melbourne's research publications}

Minerva Access is the Institutional Repository of The University of Melbourne

Author/s:

Fonmanu, Keresi R.;TING, LISA;Williamson, Ian P.

Title:

Dispute resolution for customary lands: some lessons from Fiji

Date:

2003

Citation:

Fonmanu, K. R., Ting, L., \& Williamson, I. P. (2003). Dispute resolution for customary lands: some lessons from Fiji. Survey Review, 37(289), 177-189.

Publication Status:

Published

Persistent Link:

http://hdl.handle.net/11343/33965 